\title{
ANALYTICAL STUDY OF THE MIHRAB DOME AT CORDOBA'S GREAT MOSQUE AND THE DETERMINATION OF ISLAMIC PRAYER TIMES IN THE UMAYYAD PERIOD
}

\author{
REEM FAROUQ ALSABBAN \\ King Abdul Aziz University, Saudi Arabia.
}

\begin{abstract}
This research addresses the correlation between the architectural design of the Mihrab dome at Cordoba's Great Mosque and the determination of daytime Islamic prayer times in the Umayyad period. The dome was built in the 10th century during the rule of Caliph Al-Hakam II 'Al-Mustansir Billah', who was known for his interest in sciences, specifically in the field of astronomy. The vast development of astronomical sciences during the Umayyad Caliphate, alongside the engineering sciences, helped in building the dome. This research provides an architectural analysis of the dome of the Great Mosque, the surrounding internal spaces and the interior design of the mosque. The research also provides a solar analysis around the dome supported by multiple field visits to the mosque to determine the relationship between sunlight and the mosque and how this relationship resulted in determining prayer times. To prove the correlation, a simulation analysis was applied using Autodesk software and Photoshop. Additionally, the sun path diagram was used to develop a concept from an engineering perspective. The analysis has shown that at the time of Dhuhr prayer (at noon), the window facing the sun reflects a beam of light that passes through the arches nearby the dome and illuminates the crown of a specific column inside the mosque, thereby announcing the prayer time.
\end{abstract}

Keywords: Al-Andalus, Cordoba mosque, design, dome, Islamic architecture, Mihrab, Umayyad period.

\section{INTRODUCTION}

Islamic architecture also involved the surrounding environment; for instance, a relationship between the building and the sun was established, and buildings were designed to follow this relationship. The external environment was a source for their architectural innovation, which involved the improvisations of courtyards and the wind catcher (Malqaf) as well as other elements developed by Muslim architects according to their beliefs.

Muslim architects utilized various scientific theories in their pursuit of structural design, including mathematics, physics and astronomy. Since Muslims in general associate with certain times and locations, they paid attention to timing for three key purposes: calculating prayer times, determining the direction of Ka'ba (qibla) and knowing the first month of the Islamic lunar year. This quest for time does not have a specific history but appeared particularly in the Al-Andalus area since the emergence of Islam, and mo'athins (prayer callers) were tasked with determining prayer times [1]. Muslims also made innovative clocks that worked with water, sand, mercury, wax and various other weights, in addition to inventing the solar clock in a circular shape with a central axis. With the solar clock, they were able to find the position of the sun and hence were able to develop annual calendars. The solar clock specifically represented a key feature of various religious buildings. 
However, the relationship between buildings and the sun was not a specific feature of Islam, as various models that were used to determine calendars and celebrate events were found dated to the era before Christ. Examples include the perpendicularity of the sun on the statues of Ramesses II inside the Abu Simbel temple in Aswan, Egypt [2], in Petra [3] and on the massive stones in Stonehenge, UK [4]. In modern times, this perpendicularity phenomenon occurs twice a year in Manhattanhenge [5]. In Al-Andalus, studies have proven the relationship between the sun, time and the buildings built during that period, as seen in the Hall of the two Sisters in Alhambra Palace [6] and the theories of the relationship between the 'Court of the Lions' and time determination in previous ages [7].

\section{LITERATURE REVIEW}

Various literatures were reviewed to cover three different aspects of the research. The first relates to historical literature that discusses the relationship between the sun and buildings; the second relates to literature associated with determining noon prayer time and the third relates to literature associated with technical- and engineering-related studies of the dome of Mihrab.

\subsection{Study of the relationship between the sun and buildings}

The study by Belmonte et al. [3] is considered as one of the most important studies in this area. This study revealed the association of the ancient Nabataean kingdom with the sun to light sacred sites. A research team analysed the spatial orientation of various monuments, templates and holy tombs, and compared the collected data with information about the perpendicularity of buildings with the sun in the horizon. The results indicated that during specific times of the year, the sun shines perpendicularly over the city's most important buildings, specifically during the winter solstice time, as according to their beliefs this moment is associated with the birth of the sun god. Moreover, as the sun sets, it creates shadows and light around the sacred platform inside the holy premises and the location where festivals are conducted.

\subsection{Studies related to determining the noon prayer time}

Many studies were conducted to determine the noon prayer time for Muslims. One of the most important is by Oudah [8], which included an in-depth discussion of the different ways in calculating noon prayer time. Another study by Bekli et al. [9] was conducted in Northwest Africa, as this area is in proximity to the Al-Andalus area. The study was concerned with the technical aspects of calculating noon prayer time in this area, in a manner that was not handled before. It also discussed the controversy related to adjusting the astrolabe in the scriptures, in addition to focusing on detection apparatus. Moreover, they presented various historical findings associated with water and sand clocks in the West, which were not studied before.

\subsection{Studies associated with the technical aspects of the dome of Mihrab}

Many studies were conducted on the dome of Mihrab, most of which focused on its technical and engineering aspects, without analysing the space around it adequately. However, the information gained from these studies was used to analyse the dome's dimensions. González and Fernández [10] analysed the dome of Caliph Al-Hakam II from engineering and technical 
aspects. It included analytical drawings of the dome, the engineering structure and its technical and historical roots. On the other hand, a study by Ruiz [11] included work done by a research team on the domes of the Mosque of Cordoba, especially the section that includes the great Mihrab dome. The study introduced zoomed pictures of the dome from the outside containing the opening in the dome and its windows. The materials used in the dome were also analysed from a historical perspective and the study also considered the dome's restoration. Salim [12] presented a beautiful and accurate demonstration of the Mihrab dome and the construction dimensions that contributed to the building process from a historical point of view.

To the best of our knowledge, no previous research has covered the correlation between the architectural design of the Mihrab dome at Cordoba's Great Mosque and the determination of Islamic prayer times.

\section{DETERMINING PRAYER TIMES}

Muslims have three mandatory prayers during the daytime, as mentioned in their holy book, the Quran: 'Conduct the prayers around the edges of the day' (Hud, 11/114). This verse talks about two of the three parts of the day. The first part starts with sunrise. The second starts when the sun crosses the meridian. And the third starts from the middle of the meridian and sunset line. The sun was mentioned only once in verses where a talk about the time of prayers appeared: 'Establish prayer at the decline of the sun [from its meridian] until the darkness of the night and [also] the Qur' an of dawn. Indeed, the recitation of dawn is ever witnessed' ( $\mathrm{Al}$ isra'a, 17/78). The verse mentions that the noon prayer starts with the passing of the sun through the meridian, which is easy to find in any given area. These standards are applied in the central region of the Earth that is located between $45^{\circ}$ north and $45^{\circ}$ south which the city of Cordoba is part of [13].

\section{THE MOSQUE OF CORDOBA}

Cordoba's Great Mosque is considered as one of the most astonishing Islamic mosques in the Al-Andalus region, and was the third largest mosque during the Umayyad Caliphate. Arab conquerors adopted the policy of Khalid Bin Alwalid with the People of Damascus in dividing churches in half between Christians and Muslims, as the church was divided in half between Christians and Muslims, as the church was divided in half between Christians and Muslims of Al-Andalus. Abdulrahman Alkatib then purchased the other half with a hundred thousand dinars and allowed the construction of a church outside Cordoba.

During this period, a mosque was built imitating the style of the Prophet's Mosque in Medina with some differences, similar to the Great Mosque of Kairouan. The construction phases took two and a half centuries and witnessed the addition of various sections (Karam [14]).

\subsection{Description of the mosque}

Cordoba's Great Mosque is located near Al-Wadi River with a gross area of 21,875 $\mathrm{m}^{2}$. The mosque's walls were constructed with limestone in chunks that are $1.07-1.15 \mathrm{~m}$ in length and $0.53-0.60 \mathrm{~m}$ in width. Its depth is around $0.48 \mathrm{~m}$. The chunks were aligned in a longitudinal orientation so that the fence depth is $1.14 \mathrm{~m}$. The mosque is composed of two sections: an open-air campus and the Qibla cover that contains 11 halls with 10 perpendicular arcades over the Qibla fence. These fences are then cut by a passage, which is wider than other halls with a gable-shaped ceiling; hence, it looks like the Aqsa Mosque without the existence of arcades. Each arcade contains double arches that are inspired from the Umayyad Mosque in an almost semicircular shape, with 1,350 columns inside the Qibla hall. It can be described as a mass of columns and nodes; the mosque's engineering is a blend of Gothic and Arabic 

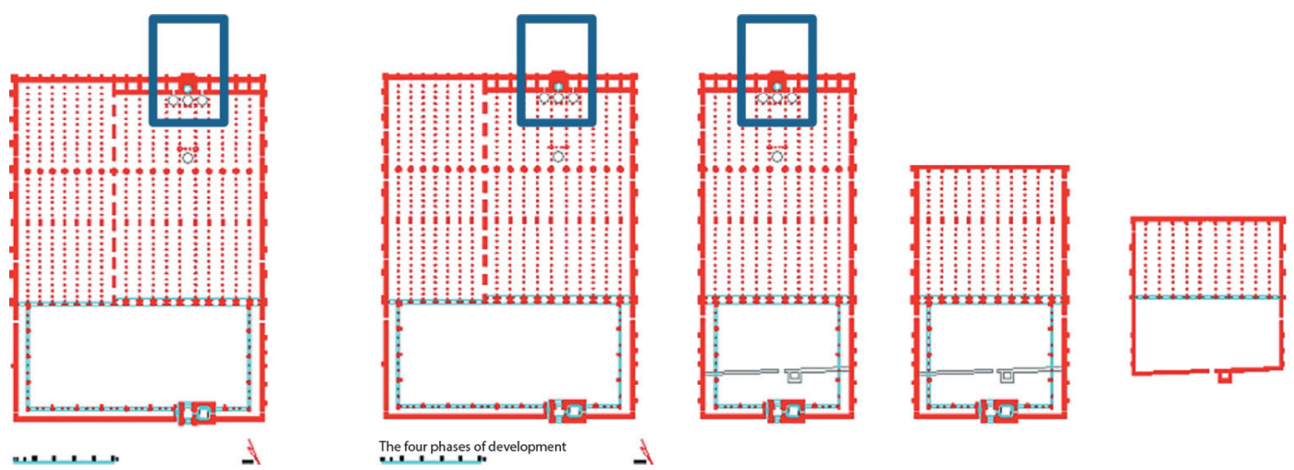

Figure 1: The location of the cabin that contains the Mihrab and the great Dome, as per the expansion of Al-Hakam II, the Great Mosque of Cordoba, shown in blue square (Arida \& Nasser [16]).

art. Due to the large area of the mosque and the fast nature of construction, its ceiling appears to be low. It was relatively simple and had basic calligraphy, with the exception of the double nodes and the alternating colours between the limestones. The ceilings did not contain domes until the period of Al-Hakam II who enriched the mosque with calligraphy and domes as well as intertwined nodes, with Arabic and Persian drawings and writings with oriental character (Karam [14]).

\subsection{Description of the dome}

The house of prayers in the Mosque of Cordoba was not large enough to host all the prayers during Fridays, which motivated Al-Hakam II to think of enlarging it. Hence, during his rule, and around the month of Ramadan of the Hijri (Islamic) year 350, he considered extensive expansion plans of the main prayer room. He delegated Jaffa'r Bin Abdulrahman to supervise the expansion efforts and to bring stones from the Cordoba Mountain to start the process. He, in fact, conducted a site visit to estimate the requirements for the expansions and possible plans for construction. The expansion included $46 \mathrm{~m}$ to the south, and hence the arch rows were extended by $1 \mathrm{~m}$ approximately. Over the entrance of the central area, a large dome with openings to allow in light was built. He also built another dome in the Hijri year 354. He surrounded this latter dome with a new Mihrab and two side domes (Fig. 1). The engineer of the mosque purposely increased the ceiling height of the central area over that of the surrounding areas, as the idea of multiple domes was new at that time (Ibrahem [15]).

\section{RESEARCH METHODOLOGY}

To confirm the hypothesis that there is indeed a relationship between the interior design of the dome space and the determination of the noon prayer time in the Umayyad era, the study's work was divided into various stages. The first stage included site visit and recording of observations in the mosque in September (summer season) as well as another visit in January (winter season), during which photos and videos were taken to record the time for sunrays during the day and the angle of incidence inside the mosque. The second phase was the historical and engineering study of the space of the dome with the aid of various studies and archives regarding dome designs. The third phase analysed the hollow interior space of the dome and its surrounding areas taking into account the relationship between Mihrab and daytime prayers, especially the noon prayer time. The aim of this study is thus to prove the 
initially stated hypothesis, with the aid of computer software and application (AutoCAD, Photoshop), as well as conducting various technical analyses.

\section{THE ANALYTICAL STUDY}

\subsection{Commencement of noon prayer time inside the building}

- Time sample: during winter, 2 January, 1:23 pm; during summer, 23 September, 2:12 pm, which is noon prayer time in Cordoba

- Spatial sample: the Mosque of Cordoba, area between Mihrab dome and the campus

- Apparatus: 16.5-megapixel Nikon D5100 camera, 8-megapixel phone camera

\subsubsection{Winter season}

The relationship between the sun and noon prayer time in the mosque (1:23 pm) was observed in winter. As the prayer time commenced, a light ray passed through one of the windows of the Mihrab dome, illuminating a column within the second row of pillars in the lower part of the dome (Fig. 2).

\subsubsection{Summer season}

The relationship between the sun and noon prayer time in the mosque $(2: 12 \mathrm{pm})$ was also observed in summer. Like the observation in winter, as the prayer time commenced, a light ray passed through one of the windows of the Mihrab dome, this time weaker than the one in winter, illuminating the same column's crown (Fig. 3).

\subsection{Engineering analysis}

To interpret this phenomenon, engineering studies were conducted, and the angles, heights and other parameters were calculated.
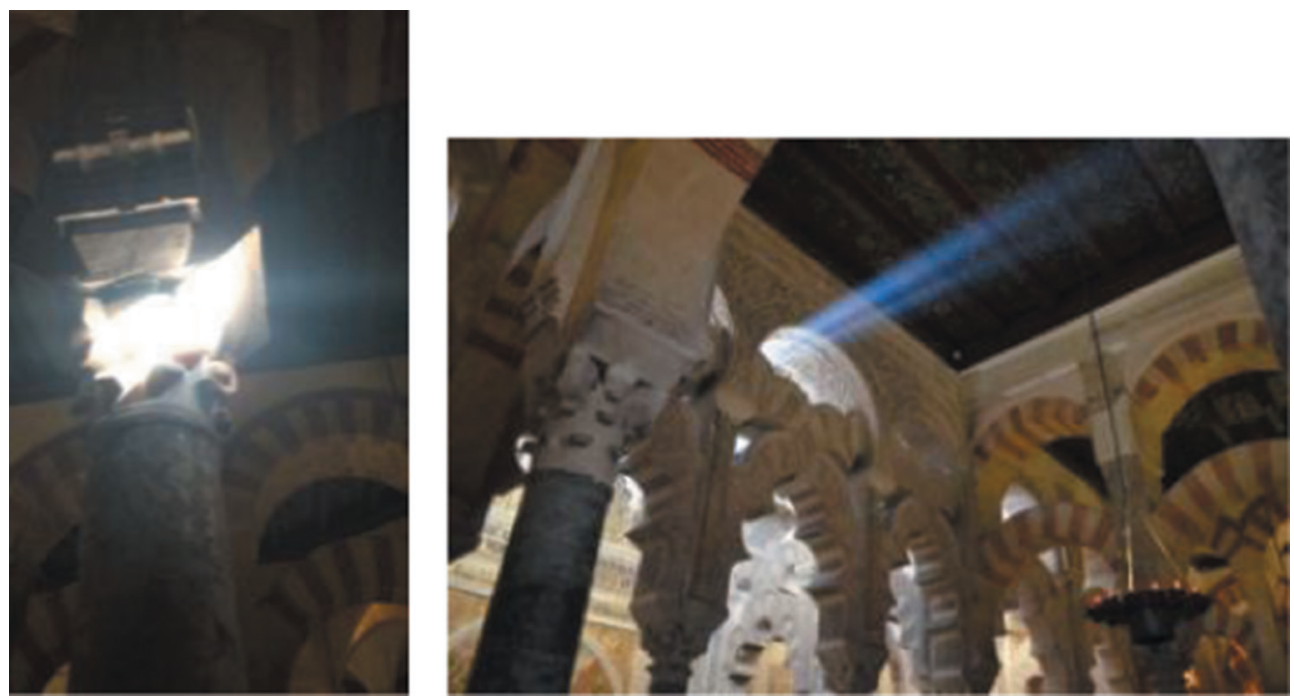

Figure 2: A specific column's crown illuminated by a light ray entering through the dome's window during winter. 

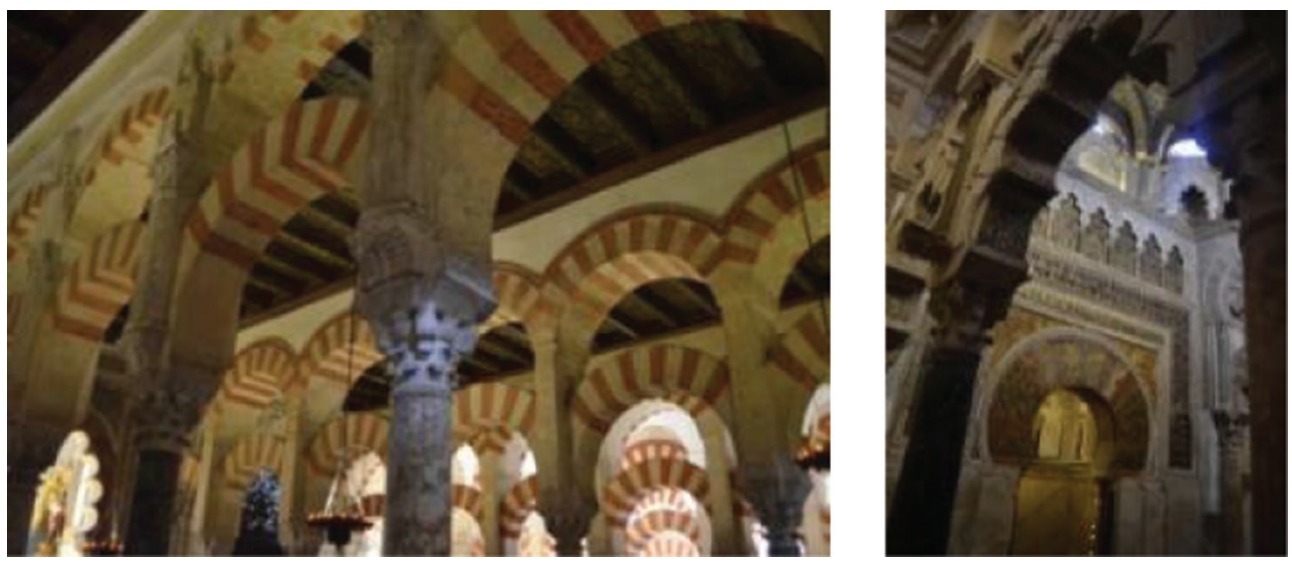

Figure 3: The same column's crown illuminated by a small light ray entering through the dome's window during summer.

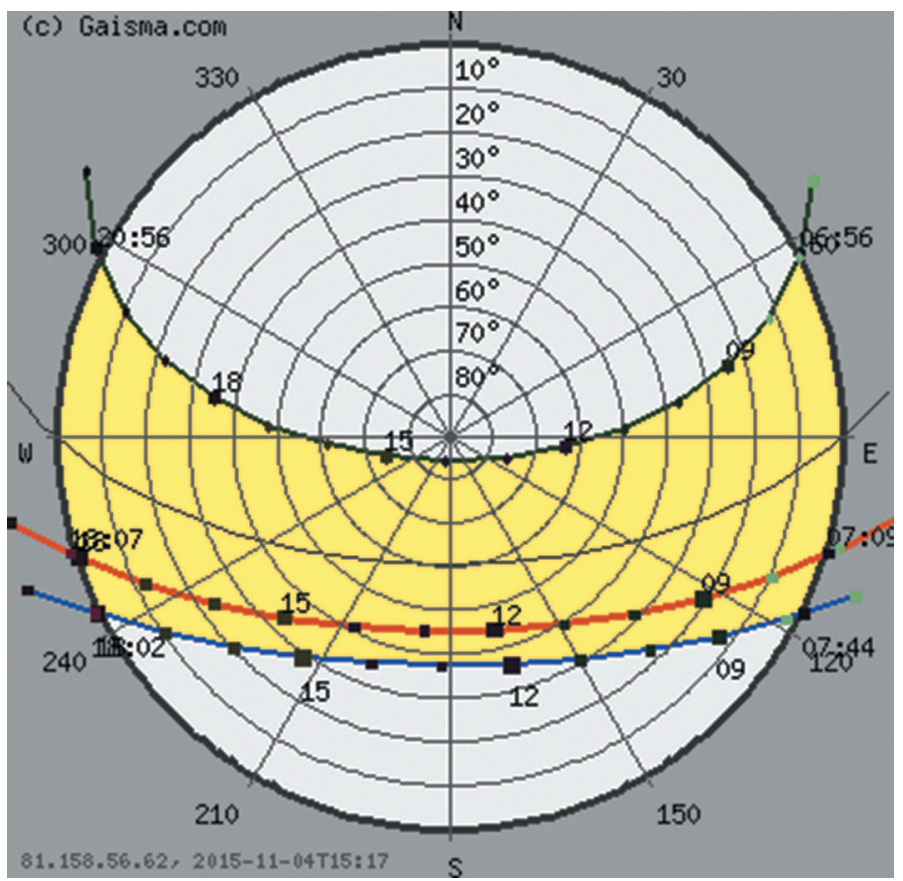

Figure 4: Sun path diagram for Cordoba city, Spain (Gaisma [17]).

\subsubsection{Geographic location of the mosque}

The mosque is located at latitude $37.8833^{\circ} \mathrm{N}, 4.7667^{\circ} \mathrm{W}$.

\subsubsection{Sun location}

The angle of the sun during the winter study was $29^{\circ}$, while during the summer it was $53^{\circ}$ (Figs. 4-6). 


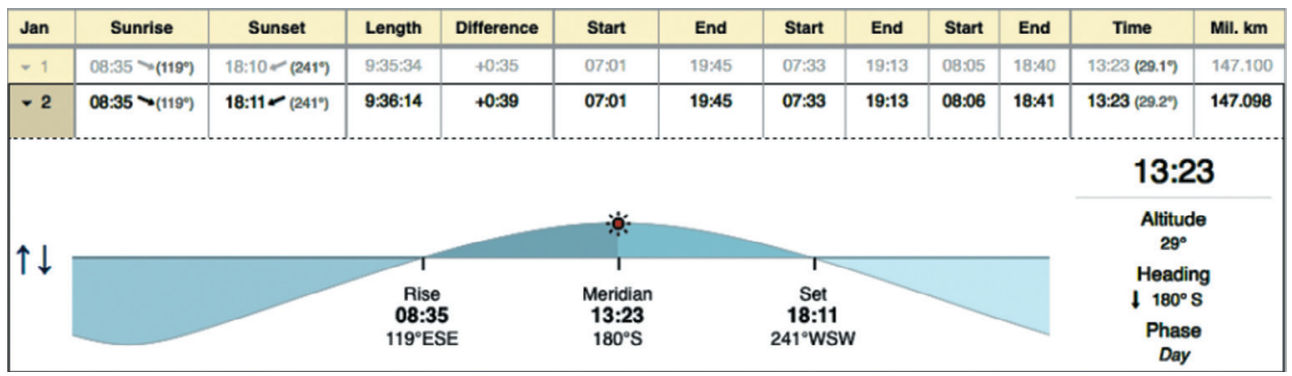

Figure 5: The altitude in winter. (TIMEANDDATE [18]).

\begin{tabular}{|c|c|c|c|c|c|c|c|c|c|c|c|c|}
\hline Sep & Sunrise & Sunset & Length & Difference & Start & End & Start & End & Start & End & Time & Mil. $\mathrm{km}$ \\
\hline-23 & $08: 07 \rightarrow\left(80^{\circ}\right)$ & $20: 15-\left(270^{\circ}\right)$ & 12:07:51 & -2.25 & 06.39 & 21:43 & 07:10 & 21:12 & 07:41 & 20:41 & 14:12 (52.19) & 150.119 \\
\hline \multirow{3}{*}{$\uparrow \downarrow$} & & & & & & & & & & & \multicolumn{2}{|c|}{ 14:12 } \\
\hline & & & & & & & & & & & \multicolumn{2}{|c|}{$\begin{array}{c}\text { Altitude } \\
52^{\circ}\end{array}$} \\
\hline & \multicolumn{4}{|c|}{$\begin{array}{l}\text { Rise } \\
08: 07 \\
89^{\circ} \mathrm{E}\end{array}$} & \multicolumn{2}{|c|}{$\begin{array}{l}\text { Meridian } \\
14: 12 \\
180^{\circ} \mathrm{S}\end{array}$} & \multicolumn{4}{|c|}{$\begin{array}{c}\text { Set } \\
20: 15 \\
270^{\circ} W\end{array}$} & \multicolumn{2}{|c|}{$\begin{array}{c}\text { Heading } \\
\downarrow 180^{\circ} \mathrm{S} \\
\text { Phase } \\
\text { Day }\end{array}$} \\
\hline
\end{tabular}

Figure 6: The altitude in summer (TIMEANDDATE [18]).

\subsubsection{Dome dimensions and holes through which sunrays enter}

Various engineering and analytical studies were conducted in Mihrab's dome, which helped in shedding light on the phenomenon of light rays falling on a particular column. For instance, the study by Ruiz [11] indicated that the dome has an octagonal shape with eight windows and calligraphy that allows the entry of light, with window width and height of $2 \mathrm{~m}$ each. The dome is $7.96 \mathrm{~m}$ wide and $6.75 \mathrm{~m}$ long in the inside as per the study by Fuentes [19]. The dome has a compound shape as seen in Fig. 7.

\subsubsection{Dome window heights}

The dome window is around $10.3 \mathrm{~m}$ high as seen in Fig. 8 .

6.2.5 Distance between the pillar and the mosque's campus hall

According to the references and figures, the distances between the pillars are $3 \mathrm{~m}$, and the target pillar is four pillars far, hence the total distance is $12 \mathrm{~m} \mathrm{[22].}$

\subsubsection{Height of the Corinthian column}

The mosque's pillars were added during the expansion carried out in Al-Hakam II's period. They are made up of marble, and have a Corinthian head. They alternate with baseless pink pillars that have compound coloured crowns, allowing the Sheikhs (Muslim scholars) and teachers to rest their backs on them while giving their lessons in the mosque. With regard to the targeted pillar, it is $3.72 \mathrm{~m}$ in height as illustrated in Fig. 8.

\subsection{Noon prayer time}

As already mentioned, noon prayer time differs day by day. For this study, the prayer times were found from the websites (Islamicfinder [23]). 


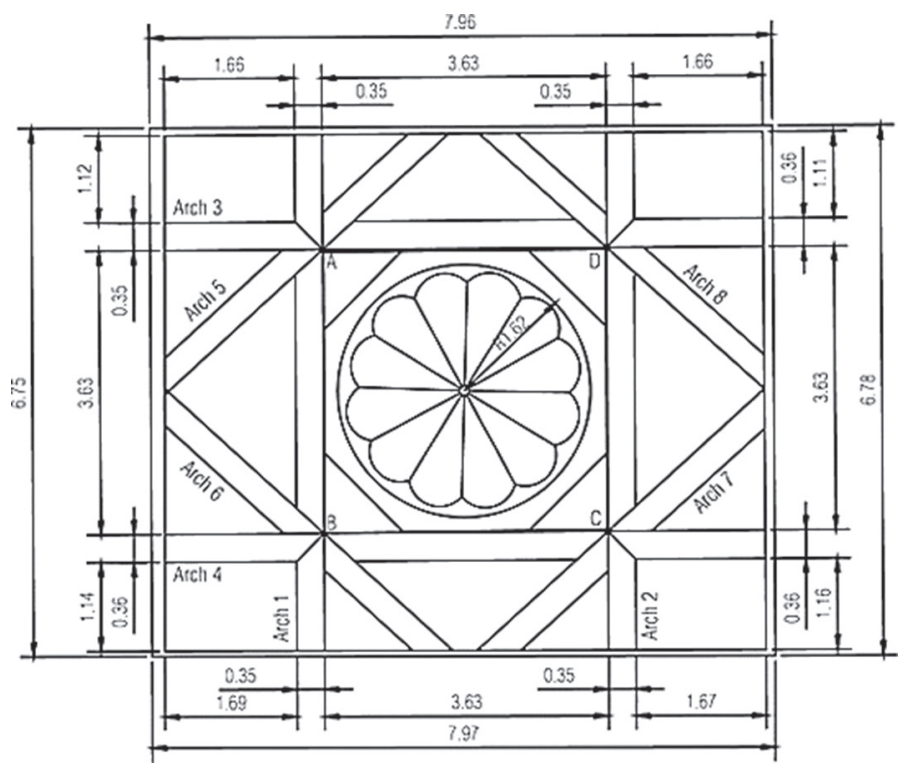

Figure 7: The dimension of the great dome (Fuentes [19]).
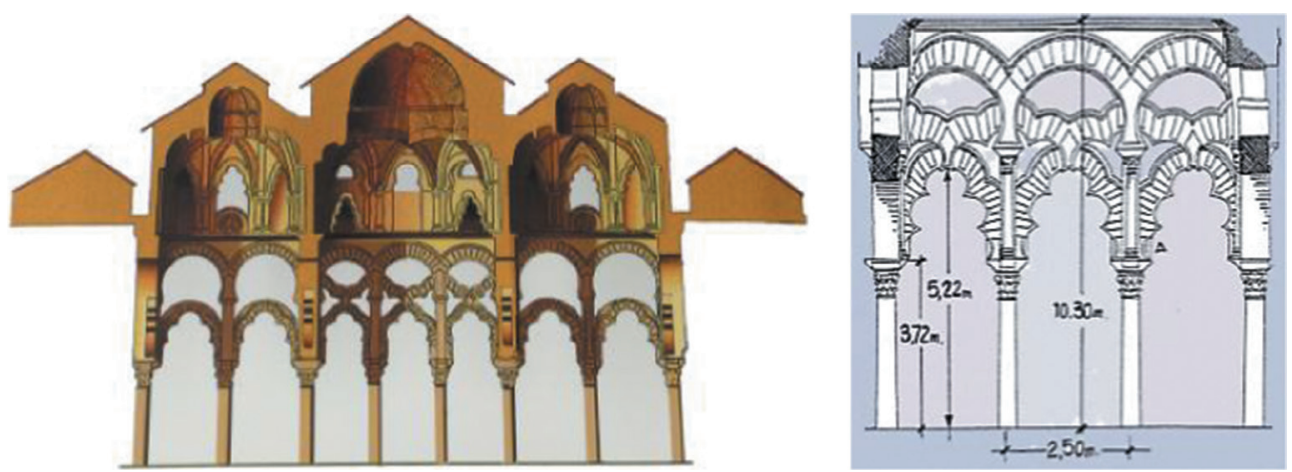

Figure 8: The height of columns in the study area (Mateo [20] and Andrade [21]).

\section{FINDINGS AND DISCUSSION}

With the previously mentioned data, we conducted computer analysis as shown in Fig. 9.

Figure 9 demonstrates that in the winter and summer seasons, when the sun is elevated at a certain angle, sunrays enter the mosque through the dome's south window, directing its rays on the crown of the Corinthian pillar, which declares the time of noon prayers. Since the sun angle is low in winter, when compared with summer, it is possible for stronger light rays to enter the mosque in the window facing the dome; these sunrays would illuminate a specific pillar out of all the surrounding pillars despite the short distance between them. Moreover, during the summer season, and although the sun is at a higher angle than that of winter, it has been noted that the exact same pillar is illuminated. After internal spatial analysis of the dome's dimensions, its windows, the Mihrab area and the pillars from one 


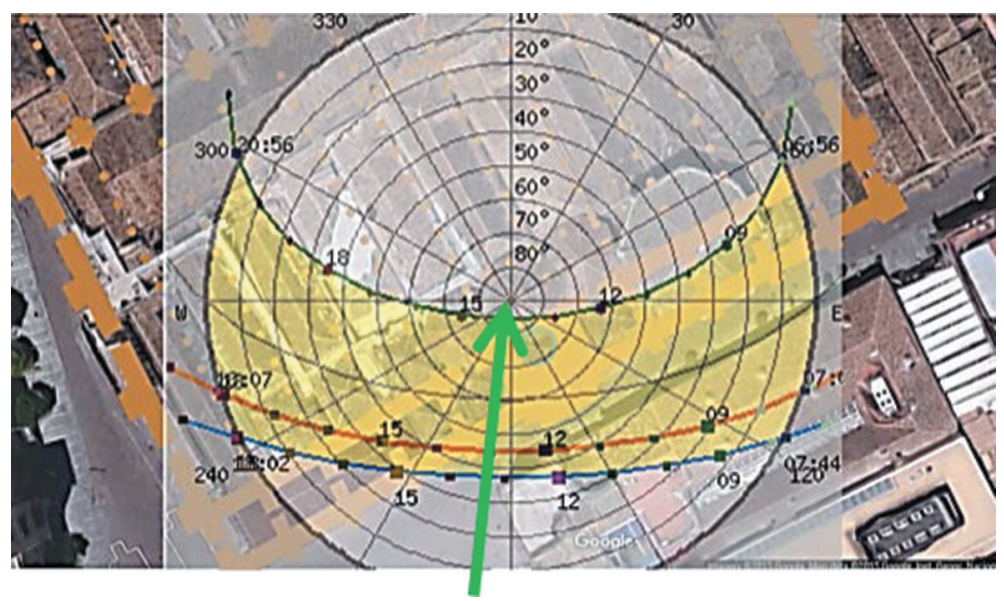

Figure 9: The direction of sunrays during noon prayer time (green arrow) using the sun diagram on the mosque's map (Gaisma [17] and GOOGLE EARTH [24]).

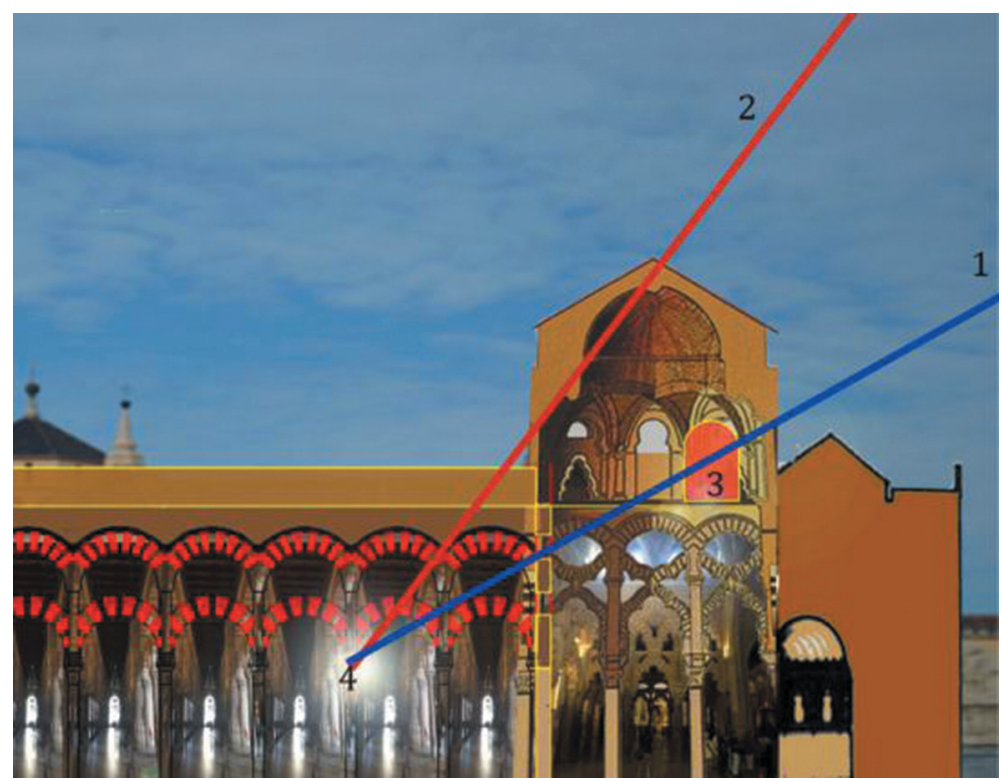

Figure 10: The blue arrow (1) shows the angle at which the sunrays enter the mosque through the window (3) during winter; the red arrow (2) shows the angle at which the sunrays enter the mosque through the window during summer, illustrating a greater angle than that of winter. The point of focus of the rays inside the mosque (4), which announces the noon prayer time (the Corinthian pillar).

side and the sun's elevation angle during noon prayer time from the other side, the hypothetical relationship can be confirmed. It states that there exists a relationship between the sun and Mihrab's dome in determining noon prayer times in the Great Mosque of Cordoba. It may be assumed that the research results may be generalized to other seasons of the year as indicated in Fig. 10. 


\section{CONCLUSIONS}

Architects and scientists have contributed effectively in designing and expanding the great Mosque of Cordoba, so that it remains a historical landmark and a witness over the AlAndalus civilization, until this very day. Historians have complemented the efforts by Caliph Al-Hakam II (Al-Mustansir Billah) by remarking that his period is the golden age for science and knowledge. It is, therefore, not strange to see those valuable unique architectural assets.

This research sheds more light on the engineering design of the Great Mosque of Cordoba's Mihrab dome and its role in determining the noon prayer time. The engineering analysis indicated that the architectural cavities in the Mihrab and its surrounding area play a key role in allowing the sunrays to enter the windows, and hence in determining the noon prayer time, as the rays illuminate the crown of a certain pillar in the mosque. The research recommends future work to focus on similar buildings around the world to learn about how humans leveraged nature and used it for religious and day-to-day activities, with a focus on the relationship between the sun and buildings during daytime.

\section{REFERENCES}

[1] Aljazirah, A.C., available at http://www.aljazeera.net/programs/aljazeeraworld/2015/7 /16/\%D8\%B9\%D9\%84\%D9\%85\%D8\%A7\%D9\%84\%D8\%AA\%D9\%88\%D9\%82\% D9\%8A\%D8\%AA\%D8\%B9\%D9\%86\%D8\%AF\%D8\%A7\%D9\%84\%D9\%85\%D8\% B3\%D9\%84\%D9\%85\%D9\%8A\%D9\%86 (accessed 8 December 2015) [Online].

[2] ALARAB, Sun and Ramses perpendicular eternal. ALARAB, 23 October (9357), p. 20, 2013.

[3] Belmonte, J.A., González-García, A.C. \& Polcaro, A., Light and shadows over Petra: astronomy and landscape in Nabataean lands. Nexus Network Journal, 15(3), pp. 487-501, 2013. DOI: 10.1007/s00004-013-0164-6

[4] Witcombe CLCE. ARTHISTORY, available at http://arthistoryresources.net/ (accessed 8 December 2015) [Online].

[5] Tyson Nd. AMNH, 2001 [Online].

[6] Acedo, A.C., The Alhambra and Generalif in Focus, Edilux S.L.: Granada, 2008.

[7] Al-Doulatli, A., Cordoba Mousqe and Alhambra Palace, Dar Aljanoub: Tunis, 1977.

[8] Oudah, M.S., Determining the Beginning of Dhohor Prayer Time, International Astronomical Center (IAC): Makkah Almukarrammah, 2015.

[9] Bekli, M.R., Shado, E. \& Jamil, E., Aspects of the timing techniques and monitoring tools in northwest Africa. International Journal for the History of Exact and Natural Sciences in Islamic Civilisation, 13, pp. 7-44, 2014.

[10] González, P.F. \& Fernández, S.H., Islamic Domes of Crossed-Arches: Origin, Geometry and Structural Behavior, College of Civil Engineering, Fuzhou University: Fuzhou, pp. 346-353, 2010.

[11] Ruiz, P.M., Archaeological study of the domes of the Maqsura at the Cordoba Mosque. Arqueología de la Arquitectura, 3, pp. 91-107, 2004, DOI: 10.3989 / arqarqt.2004.i3.

[12] Salim, A.A., The cradle of civilization in Al-Andalus Alixandria. University Youth Institute, Alixandaria, 1997.

[13] Bayander, A., available at www.hablullah.com [Online]. Available at: http://www. hablullah.com/?p=1591 (accessed 8 December 2015), 2012.

[14] Karam, K., available at http://www.alukah.net [Online]. Available at http://www. alukah.net/publications_competitions/0/40669/ (accessed 8 December 2015), 2012.

[15] Ibrahem, A., The most significant architectural trends in Alandulus during the Khalifate. Midad Aladab, Baghdad, p. 462, 2014. 
[16] Arida, S. \& Nasser, N., Archnet.org. [Online]. available at http://archnet.org/collections/ 843/publications/1237, 2003 (accessed 27 December 2015).

[17] Gaisma, available at http://www.gaisma.com/en/location/cordoba-es.html [Online] (accessed 1 January 2016).

[18] TIMEANDDATE.TIMEANDDATE.COM.[Online],availableathttp://www.timeanddate. com/sun/spain/cordoba?month=1\&year=2015 (accessed 8 December 2015).

[19] Fuentes, P., The Islamic crossed-arch domes in COldoba: geometry and structural analysis of the 'Cap illa de Villaviciosa'. Nuts \& Bolts of Construction History, eds. R. Cavias, A. Guillerme, V. Negre \& J. Sakarovitic, A\&J Picard: Paris, pp. 317-324, 2012.

[20] Mateo, M. La Mezquita Catedral de Córdoba, Edilux, 2005.

[21] Andrade, F.O., http://editorial.dca.ulpgc.es/ [Online], available at http://editorial.dca. ulpgc.es/estructuras/construccion/1_historia/17_islamica/c175.htm (accessed 1 January 2016), 2008.

[22] La Mezquita de Córdoba, empeño universal Cordoba: Ayuntamiento de Córdoba; 1973.

[23] Islamicfinder, available at http://www.islamicfinder.org/ [Online] (accessed 1 January 2016).

[24] GOOGLE EARTH, available at https://www.google.com/earth/ (accessed 8 December 2015) [Online]. 